cal juvenile-onset diabetes seems to have a much weaker genetic component. This is heartening for juvenile-onset diabetics who ask about the chances of their children becoming diabetic-they can be reassured that the risk of youth-onset diabetes in their children is probably no more than $1 \%$. Finally there is some evidence that inheritance may play a part in the development of diabetic complications. ${ }^{520}$

After years of stagnation in the study of the aetiology of diabetes these new results raise exciting possibilities of the identification-and therefore perhaps prevention-of environmental causes of the juvenile-onset type. More refined procedures, ${ }^{21}$ allied to HL-A typing, give hope that we may soon be able to identify individuals at special genetic risk.

1 Harvald, B, and Hauge, M, Acta Medica Scandinavica, 1963, 173, 459.

2 Rimoin, D L, Medical Clinics of North America, 1971, 55, 807.

3 Tattersall, R B, and Fajans, S S, Diabetes, 1975, 24, 44.

4 Dickie, M D, Advances in Metabolic Disorders, 1970, Suppl 1, 23.

5 Tattersall, R B, Quarterly Fournal of Medicine, 1974, 43, 339.

${ }^{6}$ Charles, R H, British Medical fournal, 1907, 2, 1051.

${ }^{7}$ Köbberling, J, et al, German Medical Monthly, 1969, 14, 290.

8 Tattersall, R B, and Pyke, D A, Lancet, 1972, 2, 1120.

9 Gamble, D R, et al, British Medical fournal, 1969, 3, 627.

10 Gamble, D R, and Taylor, K W, British Medical fournal, 1969, 3, 631.

1 Bloom, A, Hayes, T M, and Gamble, D R, British Medical fournal, 1975, in press.

12 Steinke, J, and Taylor, K W, Diabetes, 1974, 23, 631

${ }_{13}$ Nerup, J, et al, Lancet, 1974, 2, 864.

14 Cudworth, A G, and Woodrow, J C, Diabetes, 1975, 24, 345.

15 McDevitt, H O, and Bodmer, W F, Lancet, 1964, 1, 1269.

16 Cudworth, A G, and Woodrow, J C, British Medical fournal, 1975, 3, 133.

17 Nelson, P G, et al, Lancet, 1975, 2, 193.

18 Tattersall, R B, and Fajans, S S, Diabetes, 1975, 24, 452.

19 College of General Practitioners, British Medical fournal, 1965, 1, 960.

20 Pyke, D A, and Tattersall, R B, Diabetes, 1973, 22, 613.

21 Thomsen, M, et al, Transplantation Reviews, 1975, 22, 125.

\section{Which NHS crisis?}

Mrs Castle's statement last week (see p 182) that she is willing without any preconditions to meet the profession to discuss her proposals for phasing private beds out of NHS hospitals has gone some way towards defusing the crisis. While insisting that the Government is committed by its manifesto to separate private practice from the Health Service, she was at pains to stress that the consultants' right to opt for a part-time contract would be preserved and that her proposals for licensing private nursing homes and clinics were intended to help preserve them, not the contrary. Furthermore, she promised that her measures would be framed in such a way that her successors at the Department of Health would need further legislation if they wished to ban private practice by part-time NHS medical staff.

Her mood of reassurance extended towards the emigration figures, too: there was no evidence of mass exodus, she claimed, and furthermore those who were going were mostly full-timers or in specialties in which private practice played little part. And there was the logical slip. No one has claimed that the private-practice issue-quite unnecessarily inflamed by left-wing militants in the Labour movement-is the main cause for the low morale among NHS medical and nursing staff, though the Government's handling of the affair has offended many with no personal interest in the topic. The main problem was and is the near-bankruptcy of most parts of the NHS and the exhaustion of patience of the staff who have been propping it up for so long. Sir Rodney Smith, president of the Royal College of Surgeons, last week ${ }^{1}$ blamed the low morale among surgeons on the disparity between the resources they have been trained to expect and those provided by the NHS-and on the fact that their struggle to cope with those problems was not appreciated: instead their professional independence seemed increasingly threatened by the Department of Health.

Mrs Castle's answer to the call for better resources for the NHS was that she had raised the proportion of the gross national product spent on health to an all-time high of $5.4 \%$; yet there is clear evidence that many health authorities are unable to maintain full staff establishments because they have not got the money to pay them. Another cause for the drop in morale is the widespread conviction among clinical staff that the Service is administratively top-heavy-and Mrs Castle's retort that the structure should be blamed on Sir Keith Joseph is simply a debating point. Arguably the time is not right for the disruption that would be caused by the abolition of an administrative tier; but staff and committees could be reduced in numbers, starting at the Department of Health itself. The Government talks of a "year for Britain" and most organisations (such as the BMA) have been forced to cut their staff and their overheads-yet how far have Government departments set an example?

The call by the medical and nursing professions for an independent inquiry into NHS structure and financing is not, as Mrs Castle claims, a call for answers we already know to questions that have been asked before. Britain spends very nearly as much on health services as some of her Continental neighbours: yet NHS staff are far worse paid than any of their European colleagues and (as became clear on the BMA visit to Denmark reported at $p$ 154) the quality of the service offered to patients in Britain is also slipping behind that in the rest of Europe-at any rate north of the Alps.

The cause of the rising number of emigrants and the decline in morale among those who stay on is the progressive decline in standards-which is not seen in other countries and which is not clearly the fault of any one political administration. Something has gone wrong with the NHS: it may well have been starved of money, but even for the money it has been given we seem to have got extremely poor value. Why ? That is the question the inquiry should be asked-and if Mrs Castle knows the answer she should tell us.

1 The Times, 9 October 1975.

\section{BMA at Scanticon}

Four days in another country is far too short a time to understand its customs and way of life, but the 150 British doctors who attended the joint BMA/Danish Medical Association clinical meeting in Aarhus last month learnt a great deal in that time.

The modern hotel and conference centre at Scanticon introduced them to the cool elegance of Danish design-and to the quality and variety of the cuisine. Throughout the meeting they were made to feel really welcome. The city of Aarhus provided the setting for two magnificent evening receptions, one organised by the civic authorities and the other by the DMA itself. A wide variety of sightseeing tours was provided for non-medical members of the party, while the local general practitioners opened their surgeries and houses to their British colleagues. At the end of it all (as the report at p 154 shows) the British delegation found itself unanimous in admiration for the quality and organisation of the health services in Denmark and for the Danish way of life. Dr Erling Jacobsen, the president, Dr Bent Sterndorff, the vice president, Mr Flemming Reeslev, and Mrs Inge Nohr, the director and secretary of the Largekreds foreningen for Aarhus Amt, are to be congratulated on a splendid and memorable occasion. 